\title{
Production of 'Formosa' papaya seedlings in different protected environments and organic substrates
}

\author{
Érica Letícia Leal dos Santos ${ }^{1}$, Anne Karolyne da Silva ${ }^{1}$, Thayla Morandi Ridolfi de Carvalho \\ Curi $^{2}$, Edilson Costa ${ }^{3}$, Marçal Henrique Amici Jorge ${ }^{4}$
}

\author{
${ }^{1}$ Universidade Estadual de Mato Grosso do Sul, Unidade Universitária de Aquidauana, Aquidauana, Mato Grosso do Sul, Brasil. E- \\ mail: ericaleticialeal@hotmail.com, anneagronomia@hotmail.com \\ ${ }^{2}$ Universidade Estadual de Campinas - UNICAMP, Faculdade de Engenharia Agrícola, Campinas, São Paulo, Brasil. E-mail: \\ thaylamrcarvalho@ hotmail.com \\ ${ }^{3}$ Universidade Estadual de Mato Grosso do Sul, Unidade Universitária de Cassilândia, Cassilândia, Mato Grosso do Sul, Brasil. E- \\ mail: mestrine@uems.br \\ ${ }^{4}$ Empresa Brasileira de Pesquisa Agropecuária - Embrapa Hortaliça, Brasília, Distrito Federal, Brasil. E-mail: \\ marcal.jorge@embrapa.br
}

Recebido: 12/04/2016; Aceito: 27/05/2016.

\section{ABSTRACT}

It is aimed to evaluate the effect of cattle manure, and ground crushed cassava branches based substrates in the growth of 'Formosa' papaya seedlings under different environmental conditions. Four protected environments were tested: greenhouse in arched, covered with polyethylene film with a thermo reflective screen underneath it; similar greenhouse but without the reflective screen; monofilament nursery with $50 \%$ shade screen and thermo reflective nursery with $50 \%$ shade screen. In the protected environments, seedlings were accomodated in polyethylene bags $(15.0 \times 25.0 \mathrm{~cm})$ were filled with cattle manure, and ground cassava branches based substrates in the following proportions: $100 \%$ cassava branches; $80 \%$ cassava branches and $20 \%$ cattle manure; $60 \%$ cassava branches and $40 \%$ cattle manure; $40 \%$ cassava branches and $60 \%$ cattle manure; $20 \%$ cassava branches and $80 \%$ cattle manure and $100 \%$ cattle manure. Because there was no repetition of the culture environment, each one was considered as an experiment. The substrates with 80 and $100 \%$ cattle manure promoted better growth. The cassava branches alone is a poor substrate. The black screened and the thermo reflective proved to be the best environments.

Key words: Carica papaya; orchards; greenhouses; cattle manure; cassava branches.

\section{Produção de mudas do mamoeiro 'Formosa' em diferentes ambientes de cultivo e substratos orgânicos}

\section{RESUMO}

Objetivou-se avaliar o efeito de substratos a base de esterco bovino e ramos de mandioca triturados no crescimento de mudas de mamão 'formosa' em diferentes ambientes de cultivo. Quatro ambientes protegidos foram testados: estufa agrícola em arco, coberta com filme polietileno e tela termorrefletora sob o filme; estufa agrícola idêntica a anterior nas dimensões, porém sem a tela sob o filme; telado de monofilamento de $50 \%$ de sombreamento e telado de termorrefletora de $50 \%$ de sombreamento. Nos ambientes protegidos, as mudas foram acondicionadas em sacolas de polietileno de 15,0 × $25,0 \mathrm{~cm}$ e preenchidas com substratos a base de esterco bovino e ramos de mandioca triturados: $100 \%$ de ramos de mandioca; $80 \%$ de ramos de mandioca e $20 \%$ de esterco bovino; $60 \%$ de ramas de mandioca e $40 \%$ de esterco bovino; $40 \%$ de ramas de mandioca e $60 \%$ de esterco bovino; $20 \%$ de ramas de mandioca e $80 \%$ de esterco bovino e $100 \%$ de esterco bovino. Por não haver repetição do ambiente de cultivo, cada um foi considerado um experimento. Os substratos com 80 e $100 \%$ de esterco bovino promoveram melhor crescimento. Os ramos de mandioca pura não constituem um bom substrato. O melhor ambiente foi o de tela de monofilamento..

Palavras-chave: Carica papaya, fruticultura, estufas, esterco bovino, ramos de mandioca. 


\section{Introduction}

Papaya has great economic importance and acceptance in the global market. According to the IBGE (2010) in 2009 Brazil produced a total of 1,792,594 tons of papaya, making it the largest papaya producer in the world; with the states of Bahia and Espírito Santo leading with 891,236 and 550,057 tons respectively, and Mato Grosso do Sul occupying the 14th place. It is observed a low papaya production in the state of Mato Grosso do Sul, which imports $85 \%$ of the horticultural products for its market from other states, mainly São Paulo and Paraná. To change this unfavorable scenario, research is needed throughout the papaya production chain; starting with the seedlings formation.

The papaya orchards require constant renewal, therefore research in the seedlings production becomes imperative for the industry (LIMA et al., 2007). These are produced in containers having substrates, compounded, if possible, of readily available, low cost, local materials that help sustainability, using agricultural and/or agribusiness waste. In the interface Cerrado-Pantanal region, there is high production of cattle manure and cassava branches residues, which can be used to produce low cost and high quality papaya seedlings. For seedling vigor, the care begins with the seed and substrate quality; since they contribute to better development and directly affect the papaya's productivity and fruit quality (YAMANISHI et al., 2004).

The substrate used for the proper seedling development should meet these important requirements; availability and transport, pathogens free, rich in essential nutrients, suitable $\mathrm{pH}$, texture and structure and stimulation of the high dry weight content production in both the aerial and root parts. The addition of organic matter on the substrate influences the absorption of nutrients; thus, providing favorable conditions for the proper seedling development, which is of paramount importance for the establishment of a productive papaya orchard (YAMANISHI et al., 2004).

Allied and interacting with the substrate, the protection of the plants allow for the year-round production of high quality seedlings. Many studies have evaluated alternative materials, such as substrate, together with a protected environment for the seedlings production, in search of more vigorous and low cost plants available throughout the year (COSTA et al., 2009; COSTA et al., 2010 a). The protected environment, which was once used more intensively for the flowers production, now expands to the cultivation of fruits, especially during the seedling stage.

Araújo-Neto et al. (2010) report that the protected environment of seedlings involves climatic modifications that change the environment-plant- substrate relations. These changes may have a positive or a negative impact in plant growth. The negative effects of excess radiation, rain, and wind can be minimized in protected environments with different geometric configurations, and different wall and roofing materials, such as polyethylene film of low density and thickness, and shading screens. Studies comparing protected environments, coupled with the type substrate, from local agricultural waste, will result in papaya seedlings of high quality and vigor.

It is aimed to assess the development of 'Formosa' papaya seedlings in protected environments and with alternative substrates at base of cattle manure and crushed cassava branches.

\section{Material e Methods}

Experiments for the formation of 'Formosa' papaya seedlings were conducted in the experimental area at the State University of Mato Grosso do Sul, Aquidauana Unit University, located at an altitude of $174 \mathrm{~m}$, longitude $55^{\circ} 40^{\prime} \mathrm{W}$ and latitude $20^{\circ} 27^{\prime} \mathrm{S}$, in 2009. The region's climate from the interface between the Cerrado and the Pantanal is Aw, tropical humid, with average annual temperature of $29^{\circ} \mathrm{C}$.

There were four protected environments tested: greenhouse in arched $(8.00 \mathrm{~m}$ wide $\mathrm{x} 18.00 \mathrm{~m}$ long $\mathrm{x}$ $4.00 \mathrm{~m}$ height) of galvanized steel, with overhead opening, covered with $150 \mu \mathrm{m}$ polyethylene film with $50 \%$ aluminized thermo reflective screen placed underneath it, light diffuser, and front and side enclosures of black monofilament screen with $50 \%$ shade mesh (A1). Identical to the previous environment, but without the thermo reflective screen (A2); farm nursery with galvanized steel structure $(8.00 \mathrm{~m}$ wide $\mathrm{x}$ $18.00 \mathrm{~m}$ long $\mathrm{x} 3.50 \mathrm{~m}$ height $), 45^{\circ}$ inclination enclosure, with black monofilament screen with $50 \%$ shade mesh; nursery identical to the previous structure, but enclosed with aluminized thermo reflective screen with $50 \%$ shade mesh (A4).

For each protected environment, 'Formosa' papaya seedlings were produced in substrates at base of cattle manure and crushed cassava branches. This way the seedlings were accommodated in polyethylene bags measuring 15.0 x $25.0 \mathrm{~cm}(1.8 \mathrm{~L})$ were filled with $100 \%$ cassava branches; $80 \%$ cassava branches and $20 \%$ cattle manure; $60 \%$ cassava branches and $40 \%$ cattle manure; $40 \%$ cassava branches and $60 \%$ cattle manure; $20 \%$ cassava branches and $80 \%$ cattle manure and $100 \%$ cattle manure. Table 1 shows the substrates' chemical analysis.

The relative humidity was calculated using the Psychrometric Function Demo software (Table 2). 
Table 1. Substrates initial chemical analysis. Aquidauana-MS, 2009.

\begin{tabular}{|c|c|c|c|c|c|c|c|c|c|c|c|c|c|}
\hline & $\mathrm{pH}$ & $\mathrm{OC}$ & $\mathrm{N}$ & $\mathrm{C} / \mathrm{N}$ & $\mathrm{P}$ & K & $\mathrm{Ca}$ & $\mathrm{Mg}$ & $\mathrm{Na}$ & $\mathrm{Cu}$ & $\mathrm{Fe}$ & $\mathrm{Mn}$ & $\mathrm{Zn}$ \\
\hline & $\mathrm{CaCl}_{2}$ & & ------ & ------- & ---- & $--\%-$ & --- & $\begin{array}{l}----- \\
--1\end{array}$ & & \multicolumn{4}{|c|}{---------------mg/kg--------------- } \\
\hline S1 & $8.70 *$ & 43.15 & 0.97 & 4450.0 & 0.24 & 1.44 & 1.24 & 0.32 & 0.02 & 7.83 & 2222.73 & 103.09 & 41.85 \\
\hline $\mathrm{S} 2$ & 8.70 & 23.62 & 0.90 & 2620.0 & 0.28 & 1.08 & 0.98 & 0,28 & 0.06 & 29.07 & 11290.43 & 309.71 & 56.35 \\
\hline S3 & 8.80 & 12.95 & 0.94 & 1380.0 & 0.26 & 1.05 & 1.00 & 0.31 & 0.05 & 27.13 & 10671.00 & 307.75 & 71.75 \\
\hline S4 & 8.40 & 12.66 & 0.85 & 1490.0 & 0.30 & 0.96 & 0.95 & 0.28 & 0.07 & 26.91 & 9353.39 & 287.38 & 57.97 \\
\hline S5 & 8.65 & 16.95 & 1.06 & 1600.0 & 0.41 & 1.16 & 1.05 & 0.35 & 0.11 & 36.99 & 13780.45 & 403.02 & 84.80 \\
\hline S6 & 8.45 & 18.1 & 0.92 & 1970.0 & 0.34 & 1.11 & 0.93 & 0.28 & 0.11 & 32.84 & 11960.47 & 336.18 & 70.92 \\
\hline
\end{tabular}

OC $=$ Organic carbon; $\mathrm{S} 1=100 \%$ cassava branches; $\mathrm{S} 2=80 \%$ cassava branches and $20 \%$ cattle manure; $\mathrm{S} 3=60 \%$ cassava branches and $40 \%$ cattle manure; S $4=40 \%$ cassava branches and $60 \%$ cattle manure; S5 $=20 \%$ cassava branches and $80 \%$ cattle manure; S6 $=100 \%$ cattle manure

Table 2. Medium values of dry bulb temperature (TBS), moist bulb temperature (TBU), and relative humidity (UR) internal of each environment (A) and external area, from August 14 to October 23. Aquidauana-MS, 2009

\begin{tabular}{|c|c|c|c|c|c|c|c|c|c|}
\hline \multirow{4}{*}{$\begin{array}{l}\text { Environment } \\
\text { A1 }\end{array}$} & TBS & TBU & TBS & TBU & TBS & TBU & \multirow{2}{*}{\multicolumn{3}{|c|}{$\frac{\text { UR }}{\%}$}} \\
\hline & \multicolumn{6}{|c|}{${ }^{\circ} \mathrm{C}$} & & & \\
\hline & \multicolumn{2}{|c|}{ 09:00 AM } & \multicolumn{2}{|c|}{ 12:00 PM } & \multicolumn{2}{|c|}{ 03:00 PM } & 09:00 AM & 12:00 PM & 03:00 PM \\
\hline & 27.0 & 21.4 & 30.9 & 22.9 & 31.2 & 22,9 & 63.2 & 53.4 & 53.0 \\
\hline $\mathrm{A} 2$ & 27.5 & 21.8 & 31.2 & 23.4 & 31.5 & 23.2 & 63.2 & 54.5 & 52.6 \\
\hline $\mathrm{A} 3$ & 27.0 & 21.5 & 30.8 & 23.1 & 30.8 & 23.2 & 63.9 & 55.4 & 56.1 \\
\hline A4 & 27.4 & 22.5 & 30.9 & 24.2 & 30.6 & 24.1 & 68.3 & 60.8 & 61.3 \\
\hline Ext & 26.6 & 21.5 & 30.4 & 23.0 & 30.4 & 23.2 & 66.6 & 56.5 & 57.6 \\
\hline
\end{tabular}

A1 = greenhouse with thermo reflective screen underneath the film, A2 = greenhouse without thermo reflective screen, A3 = nursery with black monofilament screen, A4 = nursery with aluminized thermo reflective screen; Ext = external.

The cattle manure was composted for 27 days, moistened, and turned every two days. Afterwards was spread on canvas to dry and harrow. The cassava branches were ground through a hammer mill, with \#8 sieve and dried for seven days. Both cassava branches and cattle manure are abundant byproducts from Aquidauana region's agricultural industry.

On August $14^{\text {th }}, 2009$, three seeds were placed in each polyethylene bag. After the sowing and the early seedling emergence, the index assessment for the emergence speed and the emergence percentage, began on August $24^{\text {th }}$ and ended on September $3^{\text {th }}, 2009$. The counting stopped after each treatment's stabilization, i.e., same plant count for the last three samples collected. When the seedlings had two true leaves, the thinning took place, leaving one per container.

Plant height, stem diameter and the aerial and the root systems dry weight, were evaluated 71 days after sowing. They were dried in a forced circulation oven at $65^{\circ} \mathrm{C}$ for 72 hours, and subsequently measured. The dry weight sum of aerial part of the plant and root system resulted in the total dry weight. The plant height and stem diameter rates, the aerial, the root dry weights ratio, and the Dickson quality index were determined (DICKSON et al., 1960):

$$
I Q D=\frac{M S T(g)}{\frac{A P(\mathrm{~cm})}{D C(m m)}+\frac{M S A(g)}{M S R(g)}}
$$

where: IQD = Dickson quality index; $\mathrm{AP}=$ plant height; $\mathrm{DC}=$ stem diameter; $\mathrm{MSA}=$ aerial dry weight; MSR $=$ root dry weight.

Daily, at each culture environment from 08/14 to $10 / 23 / 2009$, the temperatures of dry and moist bulbs were taken at 09:00AM, 12:00, and 03:00PM, using an analog thermo-hygrometer located in the center of each protected environment, and positioned at $1,0 \mathrm{~m}$ of height of gound.

Because there was no repetition of the cropping environment, each one was considered as an experiment. A completely randomized delineation with eight replicates, two of each plant, was adopted for each environment. The data were submitted to the analysis of variance of the individual substrates, followed by the mean squares evaluation of the residues (BANZATTO; KRONKA, 2006) and the joint analysis of the experiments (groups of experiments), were performed by the Sisvar 5.3 statistical program (Ferreira 2010), and the averages comparison by the Tukey test at 5\% probability. 


\section{Results and Discussion}

The mean squares evaluation of the residues for the variables emergence speed index, emergence percentage, plant height, stem diameter, aerial dry mass, root systems dry mass, total dry mass, plant height and stem diameter rates, aerial and root dry mass ratio and Dickson quality index were 1,$4 ; 2,4 ; 2,8 ; 3,1 ; 2,1 ; 2,2$; 1,$7 ; 3,6 ; 2,1$ and 3,3 , respectively. For all variables evaluated in this study, the ratio between the residual mean squares of the individual analysis of variance of the experiments did not exceed the 7:1 ratio; therefore, allowing for their joint analysis (BANZATTO; KRONKA, 2006).

The " $F$ " of analysis of variance of the interactions between protected environment and substrates for variables emergence speed index, emergence percentage, plant height, stem diameter, aerial dry mass, root systems dry mass, total dry mass, plant height and stem diameter rates, aerial and root dry mass ratio and Dickson quality index were 99,7**, 14,45**, 876,5**,
$187,6 * *, 343,5^{* *}, 135,5^{* *}, 335,5^{* *}, 64,1^{* *}, 56,4 * *$ and $105,6 * *$ respectively, where “**” was significant at $1 \%$. Significant interactions were observed through the analysis of variance.

The interactions between substrates and environments showed that in the environments covered with polyethylene film with or without a screen underneath it, the substrates made of pure material, either cassava branches or cattle manure, led to better emergence conditions, as well as the cattle manure in the black and the thermo reflective environments (Table 3 ). In all environments it is observed that the $100 \%$ cattle manure substrate provided favorable emergence conditions, likely because of the decomposed organic matter's ability to retain water and to provide better aeration (Tables 1 and 3). These conditions, coupled with increased availability of nutrients, promoted a higher rate of seedling emergence, and consequently, greater uniformity of growth and development of the papaya tree.

Table 3. Interactions between environments and substrates for the speed of emergence index, percentage of emergence, plant height and stem diameter of the 'Formosa' papaya seedlings. Aquidauana - MS, 2009

\begin{tabular}{|c|c|c|c|c|}
\hline & $\mathrm{A} 1 * *$ & A2 & A3 & A4 \\
\hline$* * *$ & \multicolumn{4}{|c|}{ Emergence speed index } \\
\hline $100 \% \mathrm{RM}$ and $0 \% \mathrm{~EB}$ & $1.60 \mathrm{Aa}^{*}$ & $1.33 \mathrm{Aab}$ & $1.06 \mathrm{Cb}$ & $0.33 \mathrm{Ec}$ \\
\hline $80 \% \mathrm{RM}$ and $20 \% \mathrm{~EB}$ & $1.03 \mathrm{Ca}$ & $1.05 \mathrm{Ba}$ & $1.05 \mathrm{Ca}$ & $1.25 \mathrm{Ba}$ \\
\hline $60 \% \mathrm{RM}$ and $40 \% \mathrm{~EB}$ & $0.75 \mathrm{Db}$ & $0.25 \mathrm{Dc}$ & $1.77 \mathrm{Aa}$ & $0.78 \mathrm{Db}$ \\
\hline $40 \% \mathrm{RM}$ and $60 \% \mathrm{~EB}$ & $0.98 \mathrm{Cab}$ & $0.71 \mathrm{Cb}$ & $1.27 \mathrm{Ba}$ & $1.21 \mathrm{Ba}$ \\
\hline $20 \% \mathrm{RM}$ and $80 \% \mathrm{~EB}$ & $0.94 \mathrm{Cb}$ & $0.72 \mathrm{Cb}$ & $1.81 \mathrm{Aa}$ & $1.05 \mathrm{Cb}$ \\
\hline \multirow[t]{2}{*}{$0 \% \mathrm{RM}$ and $100 \% \mathrm{~EB}$} & $1.44 \mathrm{Bbc}$ & $1.20 \mathrm{Abc}$ & $1.84 \mathrm{Aab}$ & $1.96 \mathrm{Aa}$ \\
\hline & \multicolumn{4}{|c|}{ Emergence percentage } \\
\hline $100 \% \mathrm{RM}$ and $0 \% \mathrm{~EB}$ & $90.00 \mathrm{Aa}$ & $85.00 \mathrm{Aab}$ & $100.00 \mathrm{Aa}$ & $70.00 \mathrm{Bb}$ \\
\hline $80 \% \mathrm{RM}$ and $20 \% \mathrm{~EB}$ & $100.00 \mathrm{Aa}$ & $80.00 \mathrm{Ab}$ & $90.00 \mathrm{Aab}$ & $100.00 \mathrm{Aa}$ \\
\hline $60 \% \mathrm{RM}$ and $40 \% \mathrm{~EB}$ & $95.00 \mathrm{Aa}$ & $45.00 \mathrm{CDb}$ & $95.00 \mathrm{Aa}$ & $95.00 \mathrm{Aa}$ \\
\hline $40 \% \mathrm{RM}$ and $60 \% \mathrm{~EB}$ & $95.00 \mathrm{Aa}$ & $55.00 \mathrm{BCb}$ & $90.00 \mathrm{Aa}$ & $100.00 \mathrm{Aa}$ \\
\hline $20 \% \mathrm{RM}$ and $80 \% \mathrm{~EB}$ & $100.00 \mathrm{Aa}$ & $40.00 \mathrm{Db}$ & $100.00 \mathrm{Aa}$ & $95.00 \mathrm{Aa}$ \\
\hline \multirow[t]{2}{*}{$0 \% \mathrm{RM}$ and $100 \% \mathrm{~EB}$} & $95.00 \mathrm{Aa}$ & $60.00 \mathrm{Bb}$ & $90.00 \mathrm{Aa}$ & $100.00 \mathrm{Aa}$ \\
\hline & \multicolumn{4}{|c|}{ Plant height $(\mathrm{cm})$} \\
\hline RM $100 \%$ and $0 \%$ EB & $7.99 \mathrm{Ea}$ & $7.23 \mathrm{Da}$ & $7.89 \mathrm{Ea}$ & $6.25 \mathrm{Fb}$ \\
\hline $80 \% \mathrm{RM}$ and $20 \% \mathrm{~EB}$ & $25.43 \mathrm{Cc}$ & 18.75 Bd & $36.69 \mathrm{Da}$ & $32.75 \mathrm{~Eb}$ \\
\hline $60 \% \mathrm{RM}$ and $40 \% \mathrm{~EB}$ & $27.45 \mathrm{Ac}$ & $16.79 \mathrm{Cd}$ & $45.36 \mathrm{Ca}$ & $43.85 \mathrm{Db}$ \\
\hline $40 \% \mathrm{RM}$ and $60 \% \mathrm{~EB}$ & $26.64 \mathrm{ABc}$ & $20.09 \mathrm{Ad}$ & $52.75 \mathrm{Aa}$ & $46.19 \mathrm{Cb}$ \\
\hline $20 \% \mathrm{RM}$ and $80 \% \mathrm{~EB}$ & $20.73 \mathrm{Db}$ & $19.91 \mathrm{Ab}$ & $53.19 \mathrm{Aa}$ & $53.50 \mathrm{Aa}$ \\
\hline \multirow[t]{2}{*}{$0 \% \mathrm{RM}$ and $100 \% \mathrm{~EB}$} & $25.88 \mathrm{BCc}$ & $20.51 \mathrm{Ad}$ & $47.00 \mathrm{Bb}$ & $51.88 \mathrm{Ba}$ \\
\hline & \multicolumn{4}{|c|}{ Stem diameter $(\mathrm{mm})$} \\
\hline $100 \% \mathrm{RM}$ and $0 \% \mathrm{~EB}$ & $2.61 \mathrm{Ea}$ & $2.28 \mathrm{Db}$ & $2.08 \mathrm{Fb}$ & $1.63 \mathrm{Ec}$ \\
\hline $80 \% \mathrm{RM}$ and $20 \% \mathrm{~EB}$ & $7.29 \mathrm{Dc}$ & $7.01 \mathrm{Cc}$ & $8.54 \mathrm{Ea}$ & $7.63 \mathrm{Db}$ \\
\hline $60 \% \mathrm{RM}$ and $40 \% \mathrm{~EB}$ & $8.36 \mathrm{BCc}$ & $7.13 \mathrm{Cd}$ & $11.58 \mathrm{Ca}$ & $10.14 \mathrm{Cb}$ \\
\hline $40 \% \mathrm{RM}$ and $60 \% \mathrm{~EB}$ & $8.64 \mathrm{Bc}$ & 7.81 Bd & $10.94 \mathrm{Db}$ & $11.42 \mathrm{Ba}$ \\
\hline $20 \% \mathrm{RM}$ and $80 \% \mathrm{~EB}$ & $8.27 \mathrm{Cc}$ & 7.69 Bd & $12.69 \mathrm{Aa}$ & $12.16 \mathrm{Ab}$ \\
\hline $0 \% \mathrm{RM}$ and $100 \% \mathrm{~EB}$ & $10.42 \mathrm{Ac}$ & 9.81 Ad & $12.12 \mathrm{Bb}$ & $12.44 \mathrm{Aa}$ \\
\hline
\end{tabular}

* Similar uppercase letters in the columns and lowercase letters in the rows do not differ by Tukey test at $5 \%$ probability; $* * \mathrm{~A} 1=$ greenhouse with thermo reflective screen underneath the film, A2 = greenhouse without thermo reflective screen, A3 = nursery with black monofilament screen, A4 = nursery with aluminized thermo reflective screen; *** RM: cassava branches; EB: cattle manure. 
Table 1 shows that the substrate's $\mathrm{pH}$ ranged from 8.40 to 8.70 , above the suitable levels for seedlings production, which would have limited the availability of the needed nutrients. However, the resulting seedlings were of excellent quality and vigor, as expressed by the biomass parameters and the Dickson quality index for the substrates with a higher percentage of cattle manure, which contained a greater amount of nutrients available to plants

For the substrate with $100 \%$ of cattle manure, which resulted in higher percentages of emergence, the nurseries with the black and the aluminized screens propitiated environmental conditions that favored the first radicle emergence; thereafter, the hypocotyl, and the substrate rupture occurred earlier than the ones in both greenhouses. This interaction between the environment and the substrate, in which the black, and the aluminized screened environments propitiated the pluvial water seepage, and reduced the evapotranspiration (COSTA et al., 2009). As well as the porosity and the decomposed organic matter on the substrate with higher content of cattle manure, led to better physical/hydrous conditions and allowed the seed to shoot the radicle at greater speed. This variable was recorded as a function of the collection period from the faster emergence treatment; nevertheless, all substrates showed high percentages of emergence, except for those in the screen-less greenhouse (Table 3).

The combination between the organic matter porosity (ARAUJO-NETO et al., 2010), and the screened nurseries, which allowed the pluvial water seepage, and better air exchange between the internal and the external environments, provided the best conditions for seedling emergence. Since the temperatures were similar in all environments (Table 2), and because of the frequent irrigation there were no hydrous deficiency.

Through the plants height analysis, it was determined that in the greenhouse with the thermo reflective screen; the biggest seedlings were found on the substrates containing 40 and $60 \%$ of cattle manure. In the screen-less greenhouse, though, the largest plants were obtained on the substrates with 60,80 , and $100 \%$ of cattle manure. In the monofilament and thermo reflective screened nurseries, the biggest plants were found on the substrate containing $80 \%$ of manure; however, in the black monofilament nursery no differences were registered between it and the $60 \%$ substrate (Table 3).

As observed for the emergence variables, environmental conditions (screened environments) possibly interacted with the substrates' chemical and physical conditions, increasing the degradation ratios of the decomposed organic matter, resulting in taller and thicker seedlings of the 'Formosa' papaya. This shadowing effect provided by the screened nurseries probably afforded less evaporation from the substrates, while reducing plant transpiration, as observed by Costa et al. (2009); whereas, the substrates with higher manure content provided better water retention and increased availability of nutrients.

Lacerda et al. (2009) concluded that the increase in manure concentration to $30 \%$ maximum resulted in higher growth of the papaya seedlings; in this study it was also observed that higher doses produced 'Formosa' papaya seedlings of quality and vigor, as verified by the Dickson quality index. The manure's quality, the amount of nutrients as well as the treatment (composting or curing), allows for its use, either in higher or lower concentrations in agricultural substrate for plant propagation. It is probable that the environments with black, and aluminized screens, both with $50 \%$ shading, promoted environmental conditions, shading, and reduced evapotranspiration (COSTA et al., 2009), which allowed for bigger 'Formosa' papaya plants. Being is consistent with Costa et al. (2010a) findings, in which the screened environments (monofilament and aluminized) induced greater plant height and higher number of leaves throughout their "Sunrise Solo" papaya seedling experiment.

As for the stem diameters, in the low-density polyethylene environments, the plants with the thickest stems were observed on the substrate containing $100 \%$ of manure. However, in the black screened environment, the largest stem diameters were found on the substrate containing $80 \%$ manure and $20 \%$ branches. Meanwhile, in the nursery with thermo reflective screen, in relation to stem diameter, there was no significant difference between the substrates with 80 and $100 \%$ manure (Table 4). These substrates with higher percentages of manure (80 and 100\%) produced thicker stems (Table 4), as it was already observed for the plant height, and provided better aeration, water retention, and availability of nutrients. Canesin and Correia (2006) used lower percentages of manure $(50 \%)$ in their experiment. Perhaps, this work achieved the appropriate composting of this material; thus, enabling the use of higher percentages.

In the interactions for each substrate, it comes to attention that the seedlings grown on the substrate with $100 \%$ cassava branches had a larger stem diameter in the environment covered with polyethylene film with the screen underneath the film. With the substrate containing 20, 40 and $80 \%$ cattle manure, the plants with the largest stem diameter were found in the environment with the thermo reflective aluminized screen. As for the 60 and $100 \%$ manure substrates, the seedlings had larger stem diameter within the aluminized screened environment (Table 4). 
Table 4. Interactions between environments and substrates for the aerial and root dry weight and the total dry weight of "Formosa" papaya plant. Aquidauana - MS, 2009.

\begin{tabular}{|c|c|c|c|c|}
\hline \multirow[b]{2}{*}{$* * *$} & $\mathrm{~A} 1 * *$ & A2 & A3 & A4 \\
\hline & \multicolumn{4}{|c|}{ Shoot dry mass (g) } \\
\hline $100 \% \mathrm{RM}$ and $0 \% \mathrm{~EB}$ & $0.05 \mathrm{Da}^{*}$ & $0.05 \mathrm{Da}$ & $0.06 \mathrm{Fa}$ & $0.02 \mathrm{Fa}$ \\
\hline $80 \% \mathrm{RM}$ and $20 \% \mathrm{~EB}$ & $1.26 \mathrm{Cc}$ & $1.18 \mathrm{Cc}$ & $1.74 \mathrm{Ea}$ & $1.45 \mathrm{~Eb}$ \\
\hline $60 \% \mathrm{RM}$ and $40 \% \mathrm{~EB}$ & $1.58 \mathrm{Bc}$ & $1.13 \mathrm{Cd}$ & $3.03 \mathrm{Da}$ & $2.41 \mathrm{Db}$ \\
\hline $40 \% \mathrm{RM}$ and $60 \% \mathrm{~EB}$ & $1.68 \mathrm{Bc}$ & $1.43 \mathrm{Bd}$ & $3.66 \mathrm{Ca}$ & $3.00 \mathrm{Cb}$ \\
\hline $20 \% \mathrm{RM}$ and $80 \% \mathrm{~EB}$ & $1.31 \mathrm{Cc}$ & $1.42 \mathrm{Bc}$ & $4.30 \mathrm{Aa}$ & $3.87 \mathrm{Bb}$ \\
\hline \multirow[t]{2}{*}{$0 \% \mathrm{RM}$ and $100 \% \mathrm{~EB}$} & $2.02 \mathrm{Ac}$ & $1.80 \mathrm{Ad}$ & $3.82 \mathrm{Bb}$ & 4.16 Aa \\
\hline & \multicolumn{4}{|c|}{ Root dry weight (g) } \\
\hline $100 \% \mathrm{RM}$ and $0 \% \mathrm{~EB}$ & $0.03 \mathrm{Da}$ & $0.03 \mathrm{Da}$ & $0.02 \mathrm{Ea}$ & $0.01 \mathrm{Fa}$ \\
\hline $80 \% \mathrm{RM}$ and $20 \% \mathrm{~EB}$ & $0.35 \mathrm{Cb}$ & $0.47 \mathrm{BCa}$ & $0.31 \mathrm{Db}$ & $0.24 \mathrm{Ec}$ \\
\hline $60 \% \mathrm{RM}$ and $40 \% \mathrm{~EB}$ & $0.44 \mathrm{Bc}$ & $0.43 \mathrm{Cc}$ & $0.69 \mathrm{Ca}$ & $0.61 \mathrm{Cb}$ \\
\hline $40 \% \mathrm{RM}$ and $60 \% \mathrm{~EB}$ & $0.48 \mathrm{Bb}$ & $0.48 \mathrm{Bb}$ & $0.78 \mathrm{Aba}$ & $0.45 \mathrm{Db}$ \\
\hline $20 \% \mathrm{RM}$ and $80 \% \mathrm{~EB}$ & $0.31 \mathrm{Cc}$ & $0.48 \mathrm{Bb}$ & $0.75 \mathrm{Ba}$ & $0.73 \mathrm{Ba}$ \\
\hline \multirow[t]{2}{*}{$0 \% \mathrm{RM}$ and $100 \% \mathrm{~EB}$} & $0.60 \mathrm{Ad}$ & $0.68 \mathrm{Ac}$ & $0.81 \mathrm{Ab}$ & $0.98 \mathrm{Aa}$ \\
\hline & \multicolumn{4}{|c|}{ Total dry weight (g) } \\
\hline $100 \% \mathrm{RM}$ and $0 \% \mathrm{~EB}$ & $0.08 \mathrm{Da}$ & $0.08 \mathrm{Da}$ & $0.08 \mathrm{Fa}$ & $0.03 \mathrm{Fa}$ \\
\hline $80 \% \mathrm{RM}$ and $20 \% \mathrm{~EB}$ & $1.61 \mathrm{Cb}$ & $1.65 \mathrm{Cb}$ & $2.06 \mathrm{Ea}$ & $1.69 \mathrm{~Eb}$ \\
\hline $60 \% \mathrm{RM}$ and $40 \% \mathrm{~EB}$ & $2.02 \mathrm{Bc}$ & $1.56 \mathrm{Cd}$ & $3.73 \mathrm{Da}$ & $3.02 \mathrm{Db}$ \\
\hline $40 \% \mathrm{RM}$ and $60 \% \mathrm{~EB}$ & $2.13 \mathrm{Bc}$ & $1.91 \mathrm{Bd}$ & $4.44 \mathrm{Ca}$ & $3.45 \mathrm{Cb}$ \\
\hline $20 \% \mathrm{RM}$ and $80 \% \mathrm{~EB}$ & $1.62 \mathrm{Cd}$ & $1.90 \mathrm{Bc}$ & $5.05 \mathrm{Aa}$ & $4.60 \mathrm{Bb}$ \\
\hline $0 \% \mathrm{RM}$ and $100 \% \mathrm{~EB}$ & $2.61 \mathrm{Ac}$ & $2.48 \mathrm{Ac}$ & $4.63 \mathrm{Bb}$ & $5.14 \mathrm{Aa}$ \\
\hline
\end{tabular}

* Similar uppercase letters in the columns and lowercase letters in the rows do not differ by Tukey test at 5\% probability; ** A1 = greenhouse with thermo reflective screen underneath the film, A2 = greenhouse without thermo reflective screen, A3 = nursery with black monofilament screen, A4 = nursery with aluminized thermo reflective screen; *** RM: cassava branches; EB: cattle manure.

The tallest plants with the thickest stems were found in the nurseries and on the substrates with a higher percentage of cattle manure; thus, showing a proportional increase between height and stem diameter, resulting in high quality seedlings without etiolating (Table 4).

In the interaction between environment and substrate regarding the aerial dry weight and total dry weight, plants had higher ratios of biomass in the $100 \%$ manure substrates located in the environments with low-density polyethylene film and with thermo reflective aluminized screen. However, in the nursery screened with the black monofilament, the largest biomasses were observed on the substrate with $80 \%$ of cattle manure (Table 4 ).

The seedlings from the $100 \%$ branches substrate showed no difference in the aerial and the total dry weight values, within the four environments analyzed. For substrates with 20, 40, 60 and $80 \%$ of cattle manure, the seedlings showed higher ratios of aerial and total dry weight within the black monofilament screened environment. For the substrate with $100 \%$ of manure, the highest values of the aerial and the total dry weight were observed in plants grown in the aluminized thermo reflective environment (Table 4). In agreement with Costa et al. (2009) who substantiated that the papaya seedlings of the Sunrise Solo cultivar, had higher aerial dry weight when grown in thermo reflective environments, compared with those grown in greenhouse and monofilament environments.

The plants in the polyethylene and the aluminized thermo reflective environments produced the highest root dry weight in the $100 \%$ manure substrate. No dry weight discrepancies between the seedlings from the substrates with $60 \%$ and $100 \%$ of manure contents were unique to the black monofilament environment (Table 4). Again, as observed in other variables, the substrates with the highest percentage of manure led to greater plant biomass. According to Mendonça et al. (2003) substrates based on cattle manure, charcoal, soil and sand in the ratio 2:1:1:1 v/v, were a good alternative for the formation of the Sunrise Solo papaya seedlings. In this study, a larger proportion of manure (80-100\%) allowed for better development of the 'Formosa' papaya seedlings; probably because of better composting ability.

In all tested environments, no noticeable differences in root dry weight were detected in the seedlings cultivated in $100 \%$ cassava branches substrates. The substrate with $20 \%$ of manure, which presented seedlings with the highest root biomass, was located in the greenhouse without the thermo reflective screen. The highest root dry weight values, on the substrates with 40 and $60 \%$ of manure were observed in the black screened nursery. In the substrate with $80 \%$ of manure is observed that the seedlings had higher root biomass in 
the black and the aluminized nurseries. In addition, the $100 \%$ manure substrate had seedlings with the largest root biomass in the nursery with aluminized thermo reflective screen (Table 4$)$.

Table 5 shows that the substrate with $20 \%$ of manure had the highest variable height diameter ratio, within the polyethylene with screen underneath environment. Moreover, in the environment with polyethylene without screen, the $100 \%$ branches substrate had the highest ratio. Likewise, in the black screened environment it was the $60 \%$ manure substrate and in the thermo reflective were the 20,40 , and $80 \%$ ones.

The values for this height and diameter ratio could imply seedlings' etiolation. However, as observed in the previously studied variables (height, diameter and dry weight), the highest values were observed in the black and in the aluminized screened nurseries showing no etiolation; because in these environments the plants had larger diameters and biomass, and consequently, greater vigor (Table 5).

In each substrate's behavior within the culture environments, was verified that the plants grown in substrates with 0 and $20 \%$ of cattle manure had higher height and stem diameter ratios in the black and the aluminized screened nurseries. Plants from the substrates with 60,80 , and $100 \%$ cattle manure had higher ratios in the aluminized nursery. The plants from the $40 \%$ manure substrate had higher values in the black screened environment (Table 5). The plant's height division by stem diameter expresses the growth balance and the seedling' thinness; thus, estimating its growth rate after the final transplant in the field. In most environments, the lowest ratios were observed on the substrate with $100 \%$ cattle manure; consequently, indicating its ability to form the best seedlings, with greater potential for survival in the field.

In reviewing the variable aerial and root dry weight ratio, it was noticed that the highest results came from the substrate with $80 \%$ of manure, located in the environment containing the polyethylene film with screen underneath.

In the screen-less polyethylene environment, the highest ratios of biomass were observed in the substrates with 60 and $80 \%$ manure contents. In the black screened environment, the highest values were observed on the substrates with 20 and $80 \%$ of manure. In the aluminized environment, these higher rates were found on the substrate with $60 \%$ of manure (Table 5).

In forestry, this value should be about 2.0, i.e., the aerial dry weight should be double of the root, for a seedling to be regarded as of quality. In the present work, this ratio ranged from 1.84 to 6.64 . These high ratios between dry biomass are justified by the time the seedlings spent in the environment (71 days), reaching a maximum height of $53.5 \mathrm{~cm}$ and probably, the root system's development was inhibited by the container's size.

Table 5. Interactions between environments and substrates for the height and diameter ratio, aerial and root dry weight ratio, and the Dickson quality index for the 'Formosa' papaya. Aquidauana - MS, 2009.

\begin{tabular}{|c|c|c|c|c|}
\hline \multirow[b]{2}{*}{$* * *$} & \multicolumn{4}{|c|}{ Height and diameter ratio } \\
\hline & $\mathrm{A} 1 * *$ & A2 & A3 & A4 \\
\hline $100 \% \mathrm{RM}$ and $0 \% \mathrm{~EB}$ & $3.07 \mathrm{Cb}^{*}$ & $3.18 \mathrm{Ab}$ & $3.78 \mathrm{Ca}$ & $3.82 \mathrm{Da}$ \\
\hline $80 \% \mathrm{RM}$ and $20 \% \mathrm{~EB}$ & $3.49 \mathrm{Ab}$ & $2.68 \mathrm{Bc}$ & $4.30 \mathrm{Ba}$ & $4.29 \mathrm{ABa}$ \\
\hline $60 \% \mathrm{RM}$ and $40 \% \mathrm{~EB}$ & $3.28 \mathrm{Bc}$ & $2.36 \mathrm{Cd}$ & $3.92 \mathrm{Cb}$ & $4.32 \mathrm{ABa}$ \\
\hline $40 \% \mathrm{RM}$ and $60 \% \mathrm{~EB}$ & $3.08 \mathrm{Cc}$ & $2.57 \mathrm{Bd}$ & $4.84 \mathrm{Aa}$ & $4.04 \mathrm{Cb}$ \\
\hline $20 \% \mathrm{RM}$ and $80 \% \mathrm{~EB}$ & $2.51 \mathrm{Dc}$ & $2.59 \mathrm{Bc}$ & 4.19 Bb & $4.40 \mathrm{Aa}$ \\
\hline \multirow[t]{2}{*}{$0 \% \mathrm{RM}$ and $100 \% \mathrm{~EB}$} & $2.48 \mathrm{Dc}$ & $2.09 \mathrm{Dd}$ & $3.88 \mathrm{Cb}$ & 4.17 BCa \\
\hline & \multicolumn{4}{|c|}{ Aerial and root dry weight ratio } \\
\hline $100 \% \mathrm{RM}$ and $0 \% \mathrm{~EB}$ & $2.06 \mathrm{Cbc}$ & $1.84 \mathrm{Dc}$ & $3.03 \mathrm{Da}$ & $2.18 \mathrm{~Eb}$ \\
\hline $80 \% \mathrm{RM}$ and $20 \% \mathrm{~EB}$ & $3.66 \mathrm{Bc}$ & $2.54 \mathrm{Cd}$ & $5.57 \mathrm{Ab}$ & $6.10 \mathrm{Ba}$ \\
\hline $60 \% \mathrm{RM}$ and $40 \% \mathrm{~EB}$ & $3.63 \mathrm{Bb}$ & $2.64 \mathrm{BCc}$ & $4.37 \mathrm{Ca}$ & $3.97 \mathrm{Db}$ \\
\hline $40 \% \mathrm{RM}$ and $60 \% \mathrm{~EB}$ & $3.67 \mathrm{Bc}$ & $3.02 \mathrm{Ad}$ & 4.68B Cb & $6.64 \mathrm{Aa}$ \\
\hline $20 \% \mathrm{RM}$ and $80 \% \mathrm{~EB}$ & $4.23 \mathrm{Ac}$ & $2.98 \mathrm{ABd}$ & $5.72 \mathrm{Aa}$ & $5.29 \mathrm{Cb}$ \\
\hline \multirow[t]{2}{*}{$0 \% \mathrm{RM}$ and $100 \% \mathrm{~EB}$} & $3.39 \mathrm{Bc}$ & $2.64 \mathrm{BCd}$ & $4.75 \mathrm{Ba}$ & $4.26 \mathrm{Db}$ \\
\hline & \multicolumn{4}{|c|}{ Dickson quality index } \\
\hline $100 \% \mathrm{RM}$ and $0 \% \mathrm{~EB}$ & $0.015 \mathrm{Da}$ & $0.016 \mathrm{Da}$ & $0.011 \mathrm{Ea}$ & $0.005 \mathrm{Fa}$ \\
\hline $80 \% \mathrm{RM}$ and $20 \% \mathrm{~EB}$ & $0.225 \mathrm{Cb}$ & $0.317 \mathrm{BCa}$ & $0.209 \mathrm{Db}$ & $0.164 \mathrm{Ec}$ \\
\hline $60 \% \mathrm{RM}$ and $40 \% \mathrm{~EB}$ & $0.293 \mathrm{Bc}$ & $0.313 \mathrm{Cc}$ & $0.450 \mathrm{Ca}$ & $0.364 \mathrm{Cb}$ \\
\hline $40 \% \mathrm{RM}$ and $60 \% \mathrm{~EB}$ & $0.316 \mathrm{Bc}$ & $0.343 \mathrm{Bb}$ & $0.467 \mathrm{Ca}$ & $0.324 \mathrm{Dbc}$ \\
\hline $20 \% \mathrm{RM}$ and $80 \% \mathrm{~EB}$ & $0.241 \mathrm{Cd}$ & $0.343 \mathrm{Bc}$ & $0.510 \mathrm{Ba}$ & $0.475 \mathrm{Bb}$ \\
\hline $0 \% \mathrm{RM}$ and $100 \% \mathrm{~EB}$ & $0.446 \mathrm{Ac}$ & $0.525 \mathrm{Ab}$ & $0.537 \mathrm{Ab}$ & $0.609 \mathrm{Aa}$ \\
\hline
\end{tabular}

* Similar uppercase letters in the columns and lowercase letters in the rows do not differ by Tukey test at 5\% probability; ** A1 = greenhouse with thermo reflective screen underneath the film, A2 = greenhouse without thermo reflective screen, A3 = nursery with black monofilament screen, A4 = nursery with aluminized thermo reflective screen; ${ }^{* * *}$ RM: cassava branches; EB: cattle manure. 
Furthermore, all the plants grown on the substrates with $0,40,80$ and $100 \%$ of manure, had higher values within the environment with black screen. In the seedlings grown on the substrates 20 and $40 \%$ of manure, the highest ratios of biomass were observed in the aluminized screened environment (Table 5).

The Dickson quality index involves morphological parameters such as height, diameter, and dry biomass, indicating the seedling's vigor. The higher the index achieved, the better the standard of quality and the biomass distribution in the seedling. Through this index is verified that in all the protected environments; the best seedlings were formed on the substrate with $100 \%$ of manure (Table 5).

For the substrate with $100 \%$ of cassava branches, this index indicated that the environments had no influence in the quality of the seedlings. For the substrate with $20 \%$ of manure, there were improvements in the seedlings from the screen-less greenhouse. For the substrates with 40,60 and $80 \%$ of manure, the best seedlings were found in the black monofilament nursery; for the substrate with $100 \%$ manure was the thermo reflective aluminized environment (Table 5).

Therefore, for the substrates with the highest quality seedlings, the highest biomass, and the largest plants with the largest diameters (80 and 100\% manure), the environments with black and aluminized thermo reflective screens were the most likely to provide environmental condition that promoted vigorous seedlings of 'Formosa' papaya. The resulting height and number of leaves agreed with Costa et al. (2010 a). As well as with Costa et al. (2009) for the fresh and the dry biomasses from the aerial and root from the Solo Sunrise papaya; which had better results in these types of environments, noting that the height of the ceilings used in the environments were of $2.5 \mathrm{~m}$, lower than the height used in the present work $(3.5 \mathrm{~m})$. However, the results of this study contradict those obtained by Costa et al. (2010 b) when they used the $86 \%$ vermiculite + $14 \%$ Organosuper ${ }^{\circledR}$ substrate, in which the low quality seedlings were produced in the monofilament nursery, i.e., with the lowest Dickson quality index.

In all the variables, it can be seen the remarkable influence of the cattle manure on the growth, the development and the quality of the resulting seedling. Seedlings formed on substrates with $100 \%$ of manure had greater vigor, as expressed by Dickson quality index (Table 5), and were promising plants for the proper development in the field, as observed with the $80 \%$ manure substrate.

Seedlings grown in a substrate containing $100 \%$ ground cassava branches, as well as mixtures thereof with 20,40, and $60 \%$ of manure had lower growth and accumulation of biomass. Probably the high carbonnitrogen ratio (Table 1) and lower availability of nutrients in these substrates restricted the seedling's development. Perhaps the cassava branches requires composting to improve the development of the 'Formosa' papaya seedlings. In eggplant seedlings using $50 \%$ ground cassava branches, mixed with vermiculite, promoted vigorous seedlings (Costa et al. 2011) and in the present study only when $20 \%$ of it was used.

In this study, even with the cultivation and the external environments presenting similar conditions of temperature and relative humidity at the sampling times (Table 2). These conditions were different from those observed by Andrade Junior et al. (2011) for the inside and outside relative air humidity; it was found that the environments promoted differences in the variables: emergence, growth, biomass accumulation, and vigor of the papaya seedlings. The type of structure, roofing, and fencing material that altered the internal conditions of the protected environments influenced these results. Perchance the polyethylene covering promoted the greenhouse effect, resulting in lower seedling development. In the late afternoon and early evening, the greenhouses could have been storing greater amounts of thermal energy than the nurseries; thus, promoting higher temperatures and stressing the seedlings. However, this may not have occurred in both the nurseries, which allowed for better air exchange, raising the relative humidity, and decreasing water loss.

\section{Conclusions}

The substrates with 80 and $100 \%$ cattle manure promoted better seedling growth.

The cassava branches alone is not a good substrate for the formation of the 'Formosa' papaya seedling.

For the conditions of this work: the black and the thermo reflective screened nurseries produced the best 'Formosa' papaya seedlings when the well-balanced substrates, which promoted the best growth and development, were used.

\section{Acknowledgments}

The authors want to thank for scholarship on Research Produtivity granted by $\mathrm{CNPq}$ (proc. $\mathrm{n}^{\circ}$ 300829/2012-4); and by FUNDECT (proc. $\mathrm{n}^{\circ}$ 23/200.647/2012 - Call Notice FUNDECT/ CNPq No. 05/2011 - Program of First Projects - PPP)

\section{References}

ANDRADE JÚNIOR, A. S.; DAMASCENO, L. M. O.; DIAS, N. S.; GHEVY, H. R., GUISELINI, C. Climate variations in greenhouse cultivated with gerbera and relationship with external conditions. Engenharia Agrícola, Jaboticabal-SP, v. 31, n. 5, p. 857-867, 2011. 
ARAÚJO NETO, S. E.; GALVÃO, R. O.; FERREIRA, R. L. F.; PARMEJIANI, R. S.; NEGREIROS, J. R. S. Plantio direto de cebolinha sobre cobertura vegetal com efeito residual da aplicação de composto orgânico. Ciência Rural, Santa MariaRS, v. 40, n. 5, p. 1206-1209, 2010.

BANZATTO, D. A.; KRONKA, S. N. Experimentação Agrícola. 3. ed. Jaboticabal-SP: Funep, 2006. 237 p.

CANESIN, R. C. F. S.; CORRÊA, L. S. Uso de esterco associado à adubação mineral na produção de mudas de mamoeiro (Carica papaya L.). Revista Brasileira de Fruticultura, Jaboticabal-SP, v. 28, n. 3, p. 481-486, 2006.

COSTA, E.; SANTOS, L. C. R.; VIEIRA, L. C. R. Produção de mudas de mamoeiro utilizando diferentes substratos, ambientes de cultivo e recipientes. Engenharia Agrícola, Jaboticabal-SP, v. 29, n. 4, p. 528-537, 2009.

COSTA, E.; LEAL, P. A. M.; SANTOS, L. C. R.; VIEIRA, L. C. R. Crescimento de mudas de mamoeiro conduzidas em diferentes ambientes protegidos, recipientes e substratos na região de Aquidauana-MS. Acta Scientiarum. Agronomy, Maringá-PR, v. 32, n. 3, p. 463-470, 2010 a.

COSTA, E.; MESQUITA, V. A. G.; LEAL, P. A. M.; FERNADES, C. D.; ABOT, A. R. Formação de mudas de mamão em ambientes de cultivo protegido em diferentes substratos. Revista Ceres, Viçosa-MG, v. 57, n. 5, p. 679-685, set/out, 2010 b.

COSTA, E.; DURANTE, L. G. Y.; NAGEL, P. L.; FERREIRA, C. R.; SANTOS, A. Qualidade de mudas de berinjela submetida a diferentes métodos de produção. Revista Ciência Agronômica, Fortaleza-CE, v. 42, n. 4, p. 1017-1025, 2011.
DICKSON, A.; LEAF, A. L.; HOSNER, J. F. Quality appraisal of while spruce and white pine seedling stock in nurseries. The Forestry Chronicle, Mattawa-Canadá, v. 36, n. 1, p.11-13, 1960 .

FERREIRA, D. F. SISVAR - Sistema de análise de variância. Versão 5.3. Lavras-MG: UFLA, 2010.

IBGE. INSTITUTO BRASILEIRO DE GEOGRAFIA E ESTATÍSTICA. Produção Agrícola Municipal 2009. Rio de Janeiro-RJ: IBGE, 2010.

LACERDA, J. S.; PEREIRA, W. E.; DIAS, T. J.; COSTA, D. S.; BRITO NETO, J. F.; FREIRE, J. L. Produção de mudas de mamoeiro (Carica papaya) em substratos fertilizados com adubação potássica. Engenharia Ambiental: Pesquisa e Tecnologia, Espírito Santo do Pinhal-SP, v. 6, n. 1, p. 293302, 2009 .

LIMA, J. F.; PEIXOTO, C. P.; LEDO, C. A. S. Índices fisiológicos e crescimento inicial de mamoeiro (Carica papaya L.) em casa de vegetação. Ciência e Agrotecnologia, Lavras-MG, v. 31, n. 5, p. 1358-1363, 2007.

MENDONÇA, V.; ARAÚJO NETO, S. E.; RAMOS, J. D.; PIO, R.; GONTIJO, T. C. A. Diferentes substratos e recipientes na formação de mudas de mamoeiro 'sunrise solo'. Revista Brasileira de Fruticultura, Jaboticabal-SP, v. 25, n. 1, p. 127-130, 2003.

YAMANISHI, O. K.; FAGUNDES, G. R.; MACHADO FILHO, J. A.; VALONE, G. V. Efeito de diferentes substratos e duas formas de adubação na produção de mudas de mamoeiro. Revista Brasileira de Fruticultura, JaboticabalSP, v. 26, n. 2, p. 276-279, 2004. 